\title{
Lead recovery and high silica glass powder synthesis from waste CRT funnel glasses through carbon thermal reduction enhanced glass phase separation process
}

\author{
Mingfei Xing ${ }^{\mathrm{a}, \mathrm{b}}$, Zegang Fu $^{\mathrm{b}}$, Yaping Wang ${ }^{\mathrm{c}, *}$, Jingyu Wang ${ }^{\mathrm{b}}$, Zhiyuan Zhang ${ }^{\mathrm{d}}$ \\ a Henan Key Laboratory Cultivation Base of Mine Environmental Protection and Ecological Remediation, Henan Polytechnic University, Jiaozuo 454000 \\ Henan China \\ ${ }^{\mathrm{b}}$ Institute of Resource and Environment, Henan Polytechnic University, Jiaozuo 454000 Henan China \\ c School of Surveying and Land Information Engineering, Henan Polytechnic University, Jiaozuo 454000, Henan China \\ ${ }^{\mathrm{d}}$ Research Center for Eco-Environmental Sciences, Chinese Academy of Sciences, Beijing 100085, China
}

\section{H I G H L I G H T S}

- CRT funnel glass was remelted with $\mathrm{B}_{2} \mathrm{O}_{3}$ in reducing atmosphere.

- A part of $\mathrm{PbO}$ was reduced into $\mathrm{Pb}$ and detached from the glass phase.

- The rest of $\mathrm{PbO}$ and other metal oxides were mainly concentrated in the $\mathrm{B}_{2} \mathrm{O}_{3}$ phase.

- $\mathrm{PbO}$ enriched in the interconnected $\mathrm{B}_{2} \mathrm{O}_{3}$ phase can be completely leached out by $\mathrm{HNO}_{3}$.

- High silica glass powder $\left(\mathrm{SiO}_{2}\right.$ purity $>95 \%$ ) was obtained after the leaching process.

\section{A R T I C L E I N F O}

\section{Article history:}

Received 17 August 2016

Received in revised form 4 October 2016

Accepted 5 October 2016

Available online 6 October 2016

\section{Keywords:}

Hazardous waste

CRT funnel glass

Carbon-thermal reduction

Glass phase separation

Lead recovery

\section{G R A P H I C A L A B S T R A C T}

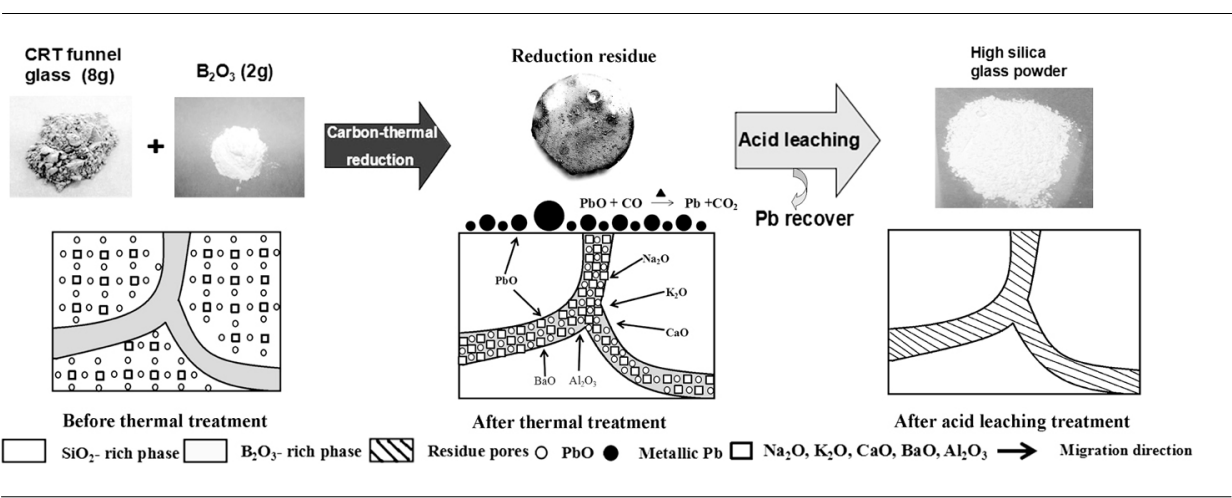

\section{A B S T R A C T}

In this study, a novel process for the removal of toxic lead from the CRT funnel glass and synchronous preparation of high silica glass powder was developed by a carbon-thermal reduction enhanced glass phase separation process. CRT funnel glass was remelted with $\mathrm{B}_{2} \mathrm{O}_{3}$ in reducing atmosphere. In the thermal process, a part of $\mathrm{PbO}$ contained in the funnel glass was reduced into metallic $\mathrm{Pb}$ and detached from the glass phase. The rest of $\mathrm{PbO}$ and other metal oxides (including $\mathrm{Na}_{2} \mathrm{O}, \mathrm{K}_{2} \mathrm{O}, \mathrm{Al}_{2} \mathrm{O}_{3}, \mathrm{BaO}$ and $\mathrm{CaO}$ ) were mainly concentrated in the boric oxide phase. The metallic $\mathrm{Pb}$ phase and boric oxide phase were completely leached out by $5 \mathrm{~mol} / \mathrm{L} \mathrm{HNO}_{3}$. The lead removal rate was $99.80 \%$ and high silica glass powder $\left(\mathrm{SiO}_{2}\right.$ purity $\left.>95 \mathrm{wt} \%\right)$ was obtained by setting the temperature, $\mathrm{B}_{2} \mathrm{O}_{3}$ added amount and holding time at $1000^{\circ} \mathrm{C}, 20 \%$ and 30 mins, respectively. The prepared high silicate glass powders can be used as catalyst carrier, semipermeable membranes, adsorbents or be remelted into high silicate glass as an ideal substitute for quartz glass. Thus this study proposed an eco-friendly and economical process for recycling Pb-rich electronic glass waste.

(c) 2016 Elsevier B.V. All rights reserved.

\footnotetext{
* Corresponding author.

E-mail address: wangyp326@163.com (Y. Wang).
}

\section{Introduction}

Cathode ray tubes (CRT) have been widely used in television sets and computer monitors. However, CRTs would eventually be replaced by an advanced display technology resulting from a 
large amount of lead-containing CRT glass for disposal [1]. Radiation protection is the main function of the CRT funnel glass that contains considerable quantities $(22 \%-25 \%)$ of toxic lead oxides [2,3]. The toxic lead oxides may be leached out when the broken lead-containing glass is mixed with acid water in waste landfills $[4,5]$. Lead has multiple deleterious health effects, especially on the human neurological and hematopoietic systems. Thus, the CRT funnel glass has been identified as a typical hazardous waste that should be recycled properly and safely.

A waste-containing CRT funnel glass can be directly prepared for use with building materials [6,7] and anti-radiation materials [8]. However, the migration of toxic lead oxides from the CRT funnel glass to the new products significantly limits the application of these methods. Meanwhile, recycling lead from a funnel glass is significant for environmental protection and lead resource cyclic utilization. Thus, a variety of advanced lead recovery methods have been developed, e.g., vacuum metallurgical methods $[9,10]$, chloride volatility process [11], reduction melting methods [12-14], and enhanced leaching methods $[15,16]$. Lead oxides were tightly enveloped in silica tetrahedrons of a funnel glass [17]; however, these special characteristics often make lead recovery methods time consuming or high energy consumption leads to high treatment costs. To reduce the processing cost, many high value-added products, including foam glass [7,9], glass microspheres [18], and high silica glass powder [14], were synchronously produced during the detoxification process of the CRT funnel glass. Among these products, high silica glass is an ideal substitute for quartz glass, and has promising economic value because of its novel properties of thermal and chemical stability, high mechanical strength, and light transmission [19].

Phase separation is the main preparation method of high silica glass. The main technique in the phase separation process involves the following three steps [20,21]: First, the alkali borosilicate glass is melted. The glass is separated into two phases, namely, $\mathrm{B}_{2} \mathrm{O}_{3}$ rich and $\mathrm{SiO}_{2}$-rich. The interconnected structure of the $\mathrm{B}_{2} \mathrm{O}_{3}$-rich phase is rich in alkali and soluble in boric oxide, especially in hot acids; The $\mathrm{SiO}_{2}$-rich phase is high in silica and stable towards acids. After hot acid leaching, the unstable $\mathrm{B}_{2} \mathrm{O}_{3}$-rich phase is leached out, leaving a porous structure with very high silica content. The prepared porous high silica glass powder could be used as semipermeable membrane, ultrafilter, catalyst carrier, and adsorbent [20]. Finally, the porous glass is remelted to more than $1200^{\circ} \mathrm{C}$, which shrinks slightly and becomes a non-porous high silica glass. Aside from some alkali metal ions, many heavy metal ions contained in a glass could also be removed by phase separation. Colored sodalime-silica glass containing heavy metal $\mathrm{Co}$ or $\mathrm{Cr}$ as a colorant was re-melted with $\mathrm{B}_{2} \mathrm{O}_{3}$ to yield a soda-lime borosilicate glass [22]. All cations ( $\mathrm{Na}, \mathrm{Ca}, \mathrm{Cr}$, and $\mathrm{Co}$ ) concentrated in the borate phase were successfully leached out with the dissolution of the borate phase. However, the traditional-phase separation process needed an annealing treatment between $500^{\circ} \mathrm{C}$ and $580^{\circ} \mathrm{C}$ for a long time to ensure complete phase separation.

Takashi Okada [14] successfully recovered lead from the funnel glass by combining reduction-melting and leaching processes. Funnel glass powder $(10 \mathrm{~g})$ was mixed with $\mathrm{Na}_{2} \mathrm{CO}_{3}(5 \mathrm{~g})$, melted at $1000^{\circ} \mathrm{C}$ for $1 \mathrm{~h}$, and annealed at $700^{\circ} \mathrm{C}$ for $2 \mathrm{~h}$ under a reductive atmosphere. In the thermal process, approximately $92 \%$ of the $\mathrm{PbO}$ in the funnel glass was reduced to metallic lead and detached from the glass phase [12]. The rest of the lead left in the reduction residue could be completely removed by $1 \mathrm{M} \mathrm{HCl}$, and porous $\mathrm{SiO}_{2}$ (purity >95 wt\%) was obtained. Therefore, the reduction-melting process could help the traditional phase-separation process to shorten the processing time based on the new generated phase of metallic $\mathrm{Pb}$. However, a large quantity of flux $\left(\mathrm{Na}_{2} \mathrm{CO}_{3}\right)$ was added into the funnel glass to promote the lead recovery while the phase separation process was used to recover the flux $\left(\mathrm{Na}_{2} \mathrm{CO}_{3}\right)$. Mean-
Table 1

Chemical composition of the investigated funnel glass by X-ray fluorescence (XRF).

\begin{tabular}{ll}
\hline Elements & wt\% \\
\hline $\mathrm{SiO}_{2}$ & 50.62 \\
$\mathrm{PbO}$ & 21.50 \\
$\mathrm{Na}_{2} \mathrm{O}$ & 10.64 \\
$\mathrm{~K}_{2} \mathrm{O}$ & 6.86 \\
$\mathrm{CaO}$ & 3.00 \\
$\mathrm{Al}_{2} \mathrm{O}_{3}$ & 2.56 \\
$\mathrm{BaO}$ & 1.18 \\
$\mathrm{SrO}$ & 0.98 \\
$\mathrm{MgO}$ & 0.92 \\
$\mathrm{Fe}_{2} \mathrm{O}_{3}$ & 0.27 \\
$\mathrm{Sb}_{2} \mathrm{O}_{3}$ & 0.27 \\
$\mathrm{ZnO}$ & 0.12 \\
$\mathrm{NiO}$ & 0.02 \\
\hline
\end{tabular}

while, $\mathrm{Na}_{2} \mathrm{CO}_{3}$ may react with $\mathrm{SiO}_{2}$, and the product of $\mathrm{Na}_{2} \mathrm{SiO}_{3}$ may cause silicon loss during the acid leaching treatment. In response to these problems, an improved method was proposed in which $\mathrm{B}_{2} \mathrm{O}_{3}$ was selected to recover lead from the funnel glass instead of $\mathrm{Na}_{2} \mathrm{CO}_{3}$ because of the following factors: (1) According to our current experiment results, the optimal $\mathrm{B}_{2} \mathrm{O}_{3}$ adding amount was approximately $20 \%$, which was smaller than the adding amount of $\mathrm{Na}_{2} \mathrm{CO}_{3}$. (2) $\mathrm{B}_{2} \mathrm{O}_{3}$ cannot be reacted with $\mathrm{SiO}_{2}$, which can effectively avoid silicon loss and obtain more high silica glass powder. Meanwhile, $\mathrm{H}_{3} \mathrm{BO}_{3}$ could be recovered from the acid leaching solution by freezing crystallization and decomposing $\mathrm{B}_{2} \mathrm{O}_{3}$ under high temperature.

Therefore, carbon-thermal reduction, which enhances the glass phase-separation process, was developed to detoxify the waste of a CRT funnel glass. The objectives of this study were to (1) discuss the transformation and migration mechanism of lead oxide in a funnel glass during carbon-thermal reduction that enhanced the phase separation process, (2) examine the effect of various experimental factors on lead removal efficiency and optimize the affecting factors, and (3) detect the chemical composition of an acid leaching residue.

\section{Materials and methods}

\subsection{Sample preparation}

The CRT funnel glass provided by Henan Hengchang Precious Metals Co. Ltd. (China) was first broken into small pieces ( $\leq 5 \mathrm{~mm}$ ), and the coatings on the glass surface were removed by wet scrubbing and ultrasonic cleaning methods [23]. Thereafter, the CRT funnel glass was milled by a dry ball and sieved through a 200 mesh sieve $(\leq 74 \mu \mathrm{m})$. The powder was dried at $105^{\circ} \mathrm{C}$ after $24 \mathrm{~h}$. The chemical composition of the glass powder was examined by X-ray fluorescence (XRF), and the results are presented in Table 1. Other materials used in the experiment were analytical reagents, unless otherwise stated.

\subsection{Carbon thermal reduction to enhance glass phase-separation process}

In the thermal reduction process, $10.0 \mathrm{~g}$ of funnel glass powder was homogeneously mixed with $0 \%-30 \% \quad \mathrm{~B}_{2} \mathrm{O}_{3}$ (particle size $<200$ mesh) by a planetary ball mill. Each mixture was placed in a $30 \mathrm{~mL}$ nickel crucible, which was placed in a rectangular corundum boat containing $20.0 \mathrm{~g}$ of carbon powder. Then, the corundum boat was placed in the tubular furnace (length, $1000 \mathrm{~mm}$; inner diameter, $70 \mathrm{~mm}$ ). The tubular furnace was sealed air-tight, and high-purity argon gas (99.999\% purity) was blown into the tubular furnace to remove the air in the chamber. The mixed powder was then heated to $700-1300^{\circ} \mathrm{C}$ and held for $30-240 \mathrm{~min}$. 
Table 2

Detailed experimental parameters of the thermal reduction process.

\begin{tabular}{lll}
\hline Temperature $\left({ }^{\circ} \mathrm{C}\right)$ & $\mathrm{B}_{2} \mathrm{O}_{3}$ adding amounts $(\%)$ & Holding time (min) \\
\hline 700 & 0 & 30 \\
800 & 5 & 60 \\
900 & 10 & 120 \\
1000 & 15 & 240 \\
1100 & 20 & \\
1200 & 25 & \\
1300 & 30 & \\
\hline
\end{tabular}

In this study, the specific thermal treatment parameters, including temperature grades, time intervals, and $\mathrm{B}_{2} \mathrm{O}_{3}$ usage are shown in Table 2. When the heating process was finished, the process chamber was slowly cooled down to room temperature. The residue in a block form was then taken out of the nickel crucible and crushed into two different particle sizes $(1-2 \mathrm{~cm}$ and $\leq 74 \mu \mathrm{m}$ ) according to the different experimental purposes. Finally, the crushed residue was stored in a desiccator for further analysis.

\subsection{Acid leaching process}

In the acid leaching treatment, $5.00 \mathrm{~g}$ of residue was placed in a $100 \mathrm{~mL}$ Teflon digestion bottle containing $20 \mathrm{~mL}$ of $\mathrm{HNO}_{3}(5 \mathrm{~mol} / \mathrm{L})$, and agitated at $90^{\circ} \mathrm{C}$ for $60 \mathrm{~min}$. The solid residue was then separated from the leaching solution by centrifuge and washed by ion-exchange water twice. Finally, the separated solid residue was dried at $105^{\circ} \mathrm{C}$ for $24 \mathrm{~h}$.

\subsection{Analysis}

The funnel glass and residue were digested by $\mathrm{HNO}_{3}-\mathrm{HClO}_{4}-\mathrm{HF}$, and the different elements contained in the funnel glass and residue were examined by an inductive coupled plasma optical emission spectrometer (ICP-OES, OPTIMA 2000). All the experiments were repeated three times and only the mean values were reported. The measurement errors were around $\pm 1 \%$. The metal removal rates in this experiment were defined as follows:

Leadremovalrates $(\%)=\left(1-\mathrm{R}^{\mathrm{Pb}} / \mathrm{R}_{0}{ }^{\mathrm{Pb}}\right) \times 100$,

$\mathrm{R}^{\mathrm{Pb}}=\mathrm{C}^{\mathrm{Pb}} / \mathrm{C}^{\text {silica }}$,

$\mathrm{R}_{0}{ }^{\mathrm{Pb}}=\mathrm{C}_{0}{ }^{\mathrm{Pb}} / \mathrm{C}_{0}$ silica .

In Eq. (3), $\mathrm{C}_{0}{ }^{\mathrm{Pb}}$ and $\mathrm{C}_{0}$ silica are the lead and $\mathrm{SiO}_{2}$ concentration of the CRT funnel glass. $\mathrm{C}^{\mathrm{Pb}}$ and $\mathrm{C}^{\text {silica }}$ are the lead and $\mathrm{SiO}_{2}$ concentration of the CRT funnel glass after acid leaching treatment. During the thermal and leaching treatments, the quantity of silicon oxide loss is negligible because of its thermal and chemical stabilities [22]. In addition, lead/silica ratio in the glass was not affected by dilution as a result of added $\mathrm{B}_{2} \mathrm{O}_{3}[12]$. Therefore, the lead/silica ratio can effectively reflect the lead concentration changes used in this experiment. The mineral composition of the reduction residue was characterized by X-ray diffraction (XRD) using the Ni-filtered $\mathrm{Cu}-\mathrm{K}$ radiation on a Rigaku D/MAX2500 diffractometer over an angle of $10^{\circ}<2 \theta<80^{\circ}$. The morphology of the acid leached residue was examined by scanning electron microscopy (SEM) equipped with an energy-dispersive X-ray spectrometer (EDS).

\section{Results and discussion}

\subsection{Characteristics of migration and transformation for $\mathrm{PbO}$ in carbon thermal reduction enhanced phase separation process}

Fig. 1 shows photos of the reduction products obtained at different temperatures when the $\mathrm{B}_{2} \mathrm{O}_{3}$ adding amount and holding time were fixed at $20 \%$ and $30 \mathrm{~min}$, respectively. When the temperature $>800^{\circ} \mathrm{C}$, the mixed glass powder began to gradually change into a liquid state and a transparent surface with a vitreous luster was obtained. At $900^{\circ} \mathrm{C}$, the transparent surface was replaced by a nontransparent surface with silver-white metallic luster, as shown in Fig. 1(c). This phenomenon indicates that some metallic oxides contained in the funnel glass assembled on the surface of the residue. At $1000^{\circ} \mathrm{C}$, plenty of large spherical particles could
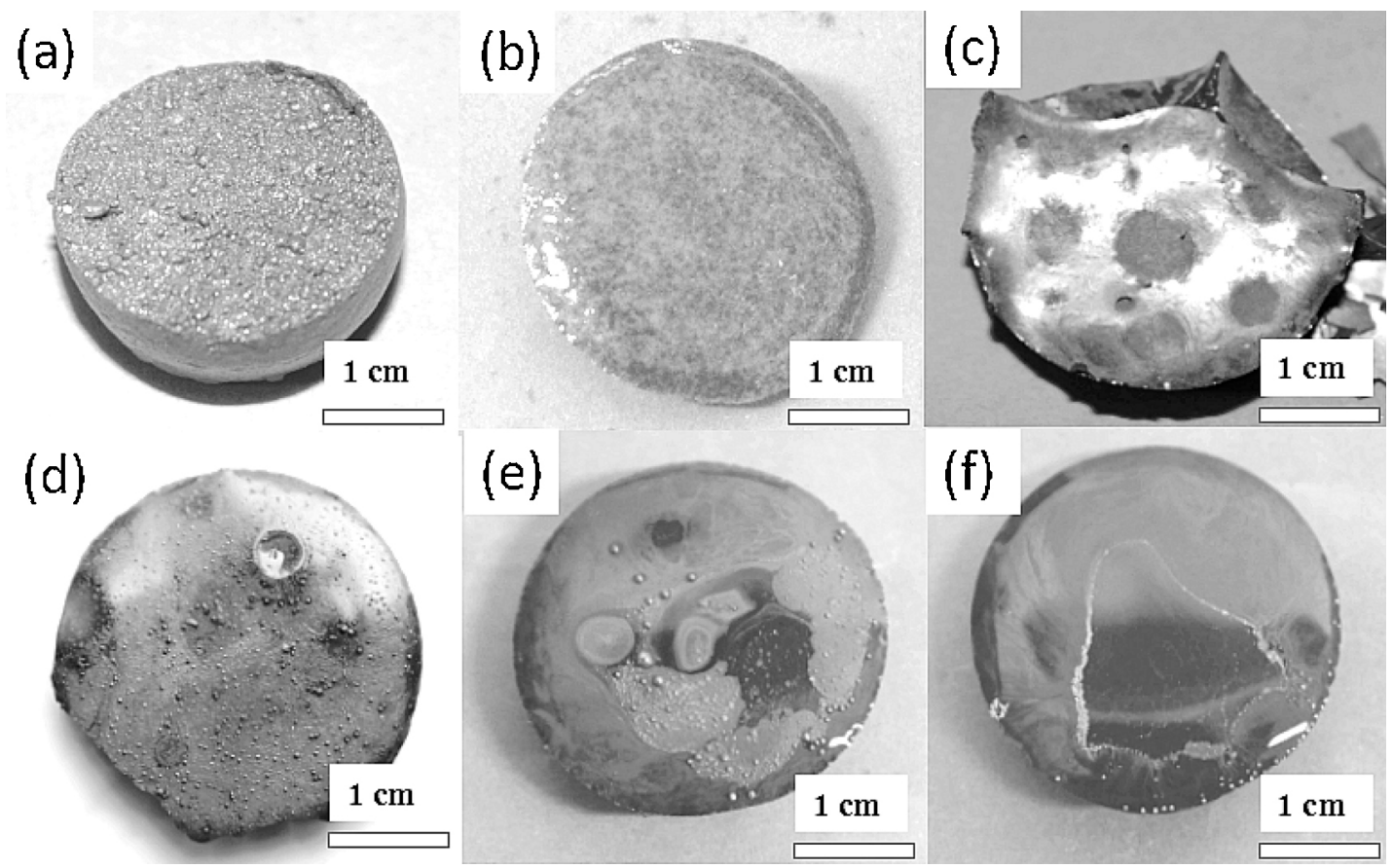

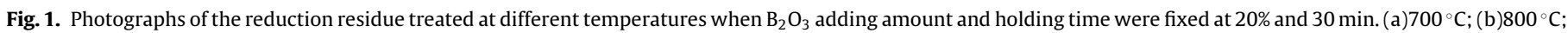
(c) $900{ }^{\circ} \mathrm{C}$; (d) $1000^{\circ} \mathrm{C}$; (e) $1200^{\circ} \mathrm{C}$; (f) $1300^{\circ} \mathrm{C}$. 


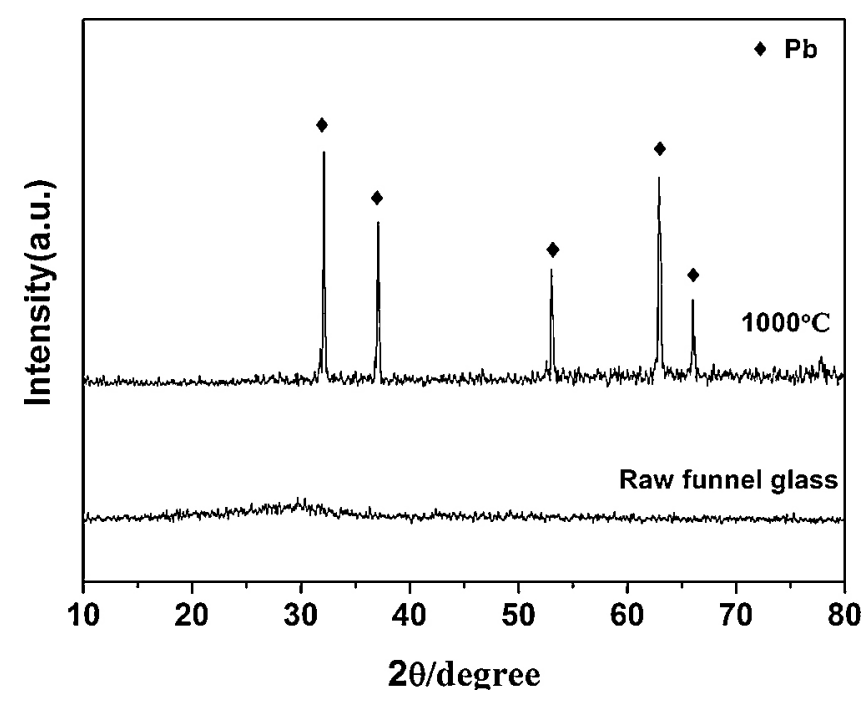

Fig. 2. XRD patterns of raw funnel glass and the formed metallic particles (temperature, $\mathrm{B}_{2} \mathrm{O}_{3}$ adding amount and reaction time were $1000^{\circ} \mathrm{C}, 20 \%$ and $30 \mathrm{~min}$ ).

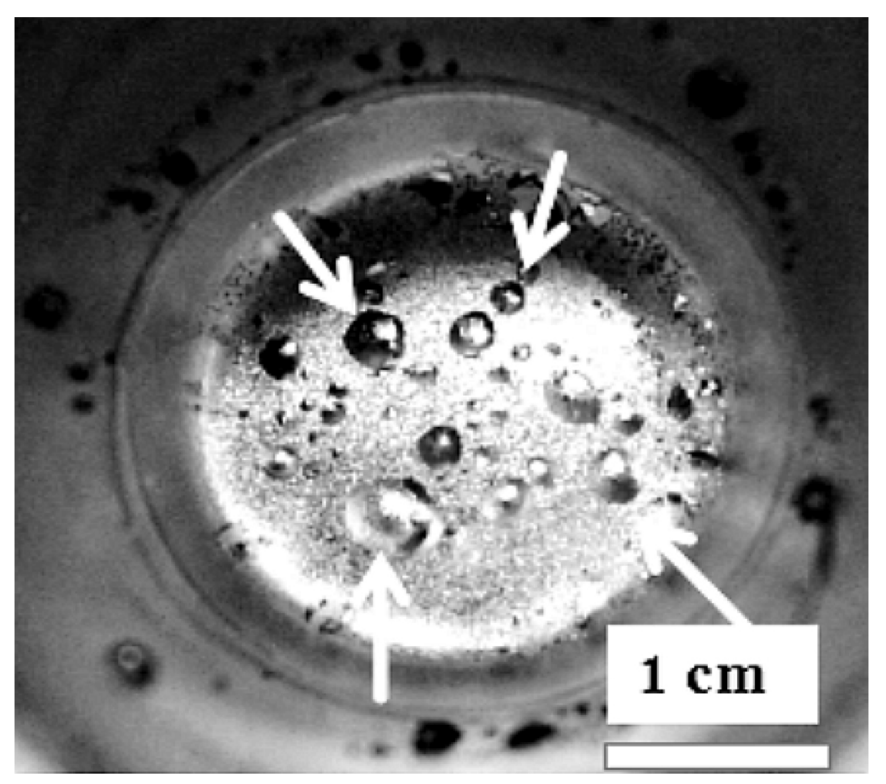

Fig. 3. Picture of the metallic lead assembled on the bottom of the nickel crucible (temperature, $\mathrm{B}_{2} \mathrm{O}_{3}$ adding amount and reaction time were $1300^{\circ} \mathrm{C}, 20 \%$ and $30 \mathrm{~min}$ ).

be seen with the naked eye on the surface of the residue. Fig. 2 shows that the raw funnel glass was non-crystalline and no characteristic peaks could be found. After thermal reduction treatment at $1000^{\circ} \mathrm{C}$, no other crystal phase except metallic lead could be observed in the XRD spectrum. Thus, the spherical particles were made up mostly of metallic $\mathrm{Pb}$. Then, the number of spherical metallic particles continued to decrease with an increase in temperature. At $1300^{\circ} \mathrm{C}$, most of the spherical metallic particles that were originally located on the surface of the reduction residue disappeared, and many large solid metallic $\mathrm{Pb}$ droplets could be found at the bottom of the nickel crucible, as shown in Fig. 3. The migration process of the metallic $\mathrm{Pb}$ during the thermal treatment could be illustrated as follows: PbO contained in the upper surface of the molten glass phase could be reduced to metallic $\mathrm{Pb}$ by $\mathrm{CO}$ existing in the gas phase. At $1000^{\circ} \mathrm{C}$, the viscosity of the glass phase was still high that most of the metallic $\mathrm{Pb}$ was located on the upper surface of the molten glass phase, as shown in Fig. 1(d). The viscosity of the glass phase was quickly decreased with an increase in temperature that led to further $\mathrm{PbO}$ reduction into $\mathrm{Pb}$ at high temperature. The liquid
Table 3

EDS results of the reduction residue obtained under the reductive atmosphere with the temperature, $\mathrm{B}_{2} \mathrm{O}_{3}$ adding amount and reaction time were fixed at $1000{ }^{\circ} \mathrm{C}, 20 \%$ and $30 \mathrm{~min}$, respectively(wt\%).

\begin{tabular}{lllllll}
\hline Elements & $\mathrm{Si}$ & $\mathrm{O}$ & $\mathrm{Pb}$ & $\mathrm{Na}$ & $\mathrm{K}$ & other \\
\hline Point A & 0 & 0 & 100 & 0 & 0 & 0 \\
Point B & 0 & 0 & 100 & 0 & 0 & 0 \\
Point C & 57.81 & 21.55 & 0 & 10.84 & 9.80 & 0 \\
Raw funnel glass & 28.90 & 26.78 & 19.78 & 12.01 & 10.53 & 2.98 \\
\hline
\end{tabular}

$\mathrm{Pb}$ particles began to collide with one another, and larger molten $\mathrm{Pb}$ droplets were formed. At $1300^{\circ} \mathrm{C}$, the viscosity of the glass phase was low enough that the molten $\mathrm{Pb}$ droplets sank from the upper surface of the molten glass phase to its bottom under the action of gravity.

The morphology and chemical composition of the spherical metallic particles on the reduction residue surface in Fig. 1(d) was examined by SEM and EDS. The metallic luster surface consisted of a layer of tiny spherical metal particles. The size of the spherical metallic particles ranged from $1.50 \mu \mathrm{m}$ to $53.18 \mu \mathrm{m}$, and most of these particles were smaller than $10 \mu \mathrm{m}$. The EDS results show that the main element of the selected spherical metal particles (points $\mathrm{A}$ and $\mathrm{B}$ ) was pure metallic $\mathrm{Pb}$. Most of the residue surface was covered by a large number of tiny spherical $\mathrm{Pb}$ particles as shown in Fig. 4(a). The formation of the spherical $\mathrm{Pb}$ particles indicated the excellent separability between the metallic $\mathrm{Pb}$ phase and the glass phase. In some small areas, a smooth surface uncovered the $\mathrm{Pb}$ particles shown in Fig. 4(c). Thus, the chemical composition of the glass phase could be detected by EDS (Table 3 ). The main element of point $\mathrm{C}$ in Fig. 4(d) was $\mathrm{Si}$, which had a weight percentage of approximately $57.81 \mathrm{wt} \%$, whereas the remaining elements and their weight percentages were $\mathrm{O}$ ( $21.55 \mathrm{wt} \%), \mathrm{Na}(10.84 \mathrm{wt} \%)$, and $\mathrm{K}$ (9.80 wt\%). As shown by the EDS results, the raw funnel glass contained approximately $19.78 \mathrm{wt} \%$ of $\mathrm{Pb}$. However, the $\mathrm{Pb}$ content of the residue decreased to $0 \%$ after the carbon thermal reduction process. The EDS comparison results between the raw funnel glass and point $\mathrm{C}$ indicated that most of the $\mathrm{PbO}$ contained in the surface of molten funnel glass was reduced to metallic $\mathrm{Pb}$ and detached from the glass phase.

However, the EDS results were semi-quantitative and could reflect only the surface chemical composition of the residue. Therefore, ICP-OES was used to examine the actual lead content of the inner part of the residue. Fig. 5 shows the lead removal rates of the carbon thermal reduction process obtained at different temperatures when the $\mathrm{B}_{2} \mathrm{O}_{3}$ adding amount and holding time were fixed at $20 \%$ and $30 \mathrm{~min}$, respectively (without acid leaching treatment). The lead removal rate was lower than $20 \%$ when the temperature was $<1000^{\circ} \mathrm{C}$. Then, the lead removal rate increased quickly and reached its maximum of $85.45 \%$ at $1300^{\circ} \mathrm{C}$. The ICP-OES results show that a certain $\mathrm{PbO}$ portion could not be reacted with $\mathrm{CO}$ and was left in the inner part of the residue during the thermal treatment. To completely remove the PbO left in the inner part of the reduction residue, the reduction residue was broken into large pieces (particle size $>1 \mathrm{~cm}$ ) by a stainless steel hammer, and then acid leaching treatment was applied to remove the PbO left in the reduction residue.

Fig. 6 shows the pictures and corresponding SEM images of the acid leaching residues obtained with different additional amounts of $\mathrm{B}_{2} \mathrm{O}_{3}$ when the temperature and holding time were fixed at $1000^{\circ} \mathrm{C}$ and $30 \mathrm{~min}$, respectively. In addition, some larger bubbles can be found in the broken residue. The foaming phenomenon is mainly attributed to the volatilization of $\mathrm{Pb}$ and $\mathrm{B}_{2} \mathrm{O}_{3}$ when the viscosity of the glass phase was higher at low temperature. After the acid leaching treatment, the surface of the residue was still smooth and characterized by vitreous luster when the added amount of $\mathrm{B}_{2} \mathrm{O}_{3}$ was $0 \%$. The vitreous luster surface indicated that a funnel 

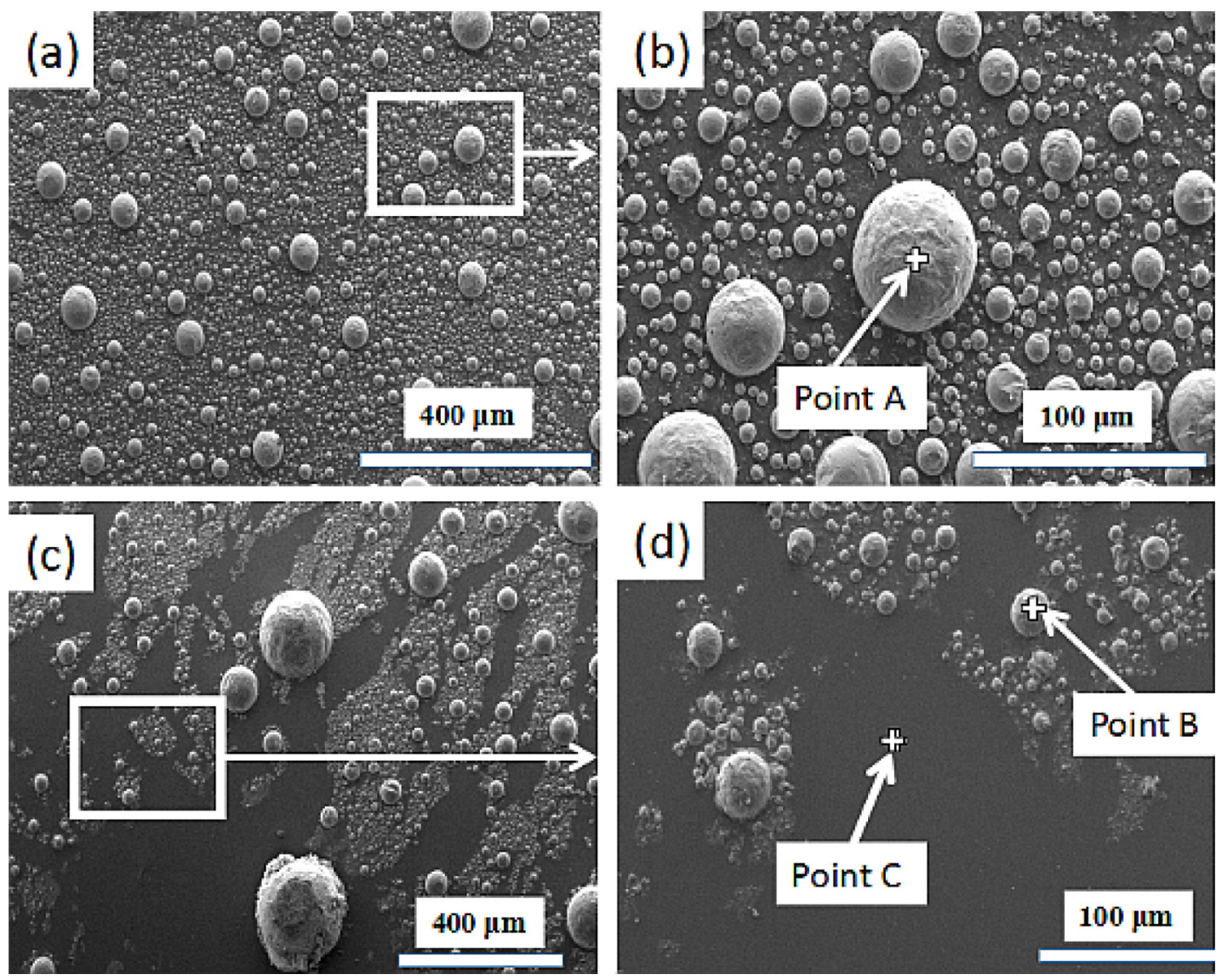

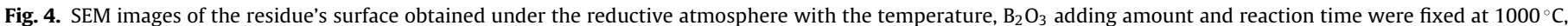
$20 \%$ and $30 \mathrm{~min}$, respectively. (b) and (d) are the corresponding partial enlarged SEM images of (a) and (d).

glass could tolerate the corrosion of a strong acid. Only a few small spherical holes were observed on the surface, as shown in Fig. 6(e). These small spherical holes were mainly attributed to the removal of spherical $\mathrm{Pb}$ particles that were originally located on the residue surface, while a part of the particle was embedded into the residue. After the acid leaching treatment, the spherical $\mathrm{Pb}$ particles were removed, leaving many circular holes on the surface of the glass. When the additional amount of $\mathrm{B}_{2} \mathrm{O}_{3}$ was increased to $10 \%$, many white stripes appeared on the surface of the residue, as shown in Fig. 6(b). Although the residue was leached in the hot $\mathrm{HNO}_{3}$ solution for $60 \mathrm{~min}$, the corrosion layer on the surface of the residue was still very thin. The corresponding SEM pictures in Fig. 6(f) show that many cracks were formed on the surface. The formation of these cracks were mainly attributed to the dissolution of $\mathrm{B}_{2} \mathrm{O}_{3}$, which was easily dissolved in hot water or hot acid. The length of the cracks range from $35.69 \mu \mathrm{m}$ to $72.78 \mu \mathrm{m}$, and the width of the cracks range from $1.71 \mu \mathrm{m}$ to $8.19 \mu \mathrm{m}$. When the added amount of $\mathrm{B}_{2} \mathrm{O}_{3}$ was increased to $20 \%$, the surface of the residue completely changed to white. The depth of the corrosion layer was about 1-2 mm, which was much thicker than that in Fig. 6(b). More large cracks could be seen on the surface of the residue in Fig. $6(\mathrm{~g})$. When $30 \%$ of $\mathrm{B}_{2} \mathrm{O}_{3}$ was mixed with a funnel glass, the reduction residue was completely corroded and splintered into small white fragments. The cracks became denser and smaller. The length of the cracks ranged from $1.47 \mu \mathrm{m}$ to $5.03 \mu \mathrm{m}$, and the width of the cracks ranged from $0.23 \mu \mathrm{m}$ to $0.92 \mu \mathrm{m}$.

Table 4 shows the EDS results of the acid leaching residue. The content of $\mathrm{Pb}, \mathrm{Na}, \mathrm{K}$, and $\mathrm{Al}$ decreased quickly when the added amount of $\mathrm{B}_{2} \mathrm{O}_{3}$ was increased, but $\mathrm{Si}$ and $\mathrm{O}$ exhibited a contrary behavior. When no $\mathrm{B}_{2} \mathrm{O}_{3}$ was added, the $\mathrm{Pb}$ content of the acid leaching residue was about $17.86 \%$ (point $\mathrm{A}$ ). When the added amount was increased to $10 \%$, Pb was completely removed, while the contents of $\mathrm{Na}$ and $\mathrm{Al}$ were $1.31 \%$ and $1.38 \%$, respectively. When $20 \%$ of $\mathrm{B}_{2} \mathrm{O}_{3}$ was added, almost all of the $\mathrm{Pb}, \mathrm{Na}, \mathrm{K}$, and $\mathrm{Al}$ were leached out, leaving only Si (52.59\%) and O (47.41\%). Therefore, $\mathrm{B}_{2} \mathrm{O}_{3}$ has a significant impact on the lead removal rate and the function of $\mathrm{B}_{2} \mathrm{O}_{3}$ can be illustrated by the following factors: (1) $\mathrm{B}_{2} \mathrm{O}_{3}$ could be used as a pore-forming agent so that the pore surface area of the cracks increases quickly with an increased in the

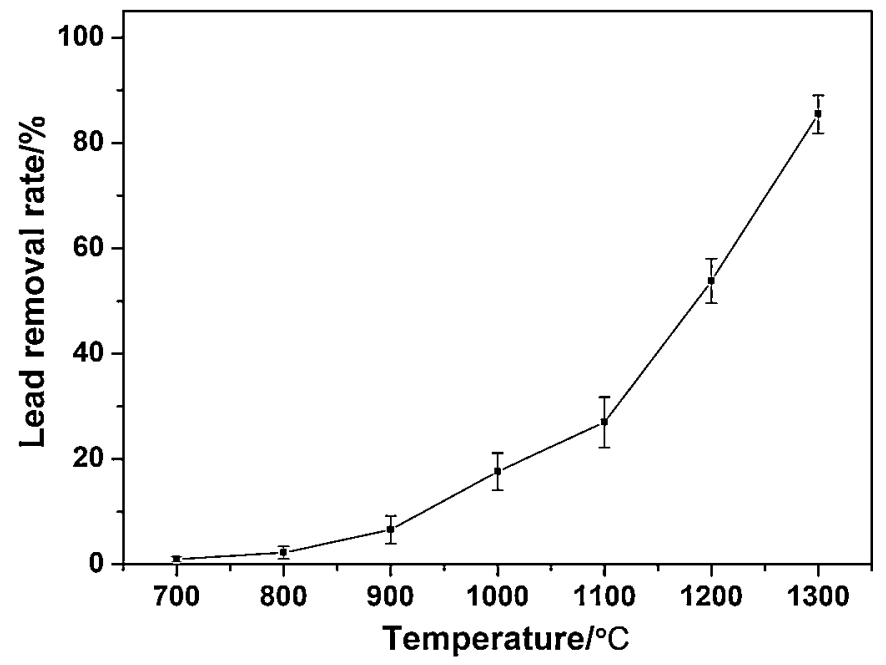

Fig. 5. The effect of temperature on the lead removal rate in the carbon thermal reduction process $\left(\mathrm{B}_{2} \mathrm{O}_{3}\right.$ adding amount $=20 \%$ and reaction time $\left.=30 \mathrm{~min}\right)$. 
Table 4

EDS results of the acid leaching residue treated with different $\mathrm{B}_{2} \mathrm{O}_{3}$ adding amounts when temperature and holding time were fixed at $1000{ }^{\circ} \mathrm{C}$ and $30 \mathrm{~min}(\mathrm{wt} \%)$.

\begin{tabular}{lllllll}
\hline Elements & $\mathrm{Si}$ & $\mathrm{O}$ & $\mathrm{Pb}$ & $\mathrm{Na}$ & $\mathrm{K}$ & $\mathrm{Al}$ \\
\hline Point A & 27.96 & 26.34 & 17.86 & 14.92 & 10.53 & 2.39 \\
Point B & 48.96 & 48.37 & 0 & 1.31 & 0 & 1.38 \\
Point C & 52.59 & 47.41 & 0 & 0 & 0 & 0 \\
Point D & 63.25 & 36.75 & 0 & 0 & 0 & 0
\end{tabular}

added amount of $\mathrm{B}_{2} \mathrm{O}_{3}$. The higher the pore surface area, the higher the $\mathrm{Pb}$ removal rate. (2) $\mathrm{B}_{2} \mathrm{O}_{3}$ could be used as a fluxing agent that reduces the viscosity of the glass phase, especially under high temperature. The lower viscosity of the glass phase can speed up the migration velocity of lead oxide from the inner part to the surface of the residue. Thus, a larger amount of $\mathrm{PbO}$ could be reduced to metallic $\mathrm{Pb}$ by $\mathrm{CO}$ in the gas phase and detached from the glass phase. (3) $\mathrm{B}_{2} \mathrm{O}_{3}$ could be used as a concentrating and phase separation agent to grab many types of metal oxide from the silica network. The unreduced $\mathrm{PbO}$ and many other metal oxides were mainly concentrated in the $\mathrm{B}_{2} \mathrm{O}_{3}$-rich phase, which could be completely leached out by an acid leaching treatment.

Therefore, the characteristics of a migration and transformation rule for $\mathrm{PbO}$ in the carbon reduction process could be described in Fig. 7. Before the thermal treatment, $\mathrm{PbO}$ and other metal oxides were evenly dispersed in the funnel glass. When the temperature was $>800^{\circ} \mathrm{C}$, the funnel glass changed gradually into a liquid state. $\mathrm{PbO}$ near the surface of the solid glass was continuously reduced to $\mathrm{Pb}$ and detached from the glass phase. Thus, the $\mathrm{PbO}$ content in the residue surface was lower than that in the inner portion such that the concentration gradient of $\mathrm{PbO}$ caused the flow of $\mathrm{PbO}$ from the inner glass phase of the surface. The viscosity of the glass phase was quickly decreased with the increase of temperature lead to $\mathrm{PbO}$ that could quickly move the surface of the glass phase. When more $\mathrm{Pb}$ assembled on the residue surface, the liquid $\mathrm{Pb}$ particles began colliding with each other, and metallic $\mathrm{Pb}$ phase was formed on the residue surface. Meanwhile, most of the unreduced $\mathrm{PbO}$ and other metal oxides migrated from the silicon oxide phase to the boric oxide phase during the thermal treatment. After the acid leaching treatment, the metallic $\mathrm{Pb}$ phase located on the surface of the residue and $\mathrm{PbO}$ contained in the interconnected boric oxide phase were completely leached out, thereby leaving a porous structure with very high silica content.

\subsection{Effects of various parameters on lead removal rate}

After the carbon-thermal reduction process, the metallic $\mathrm{Pb}$ phase was assembled on the residue surface, and unreduced $\mathrm{PbO}$ was mainly concentrated in the interconnected $\mathrm{B}_{2} \mathrm{O}_{3}$ phase. Both two-phase systems could be easily leached out by acid leaching. However, the acid corrosion velocity was quite slow and the depth of the corrosion layer was less than $2 \mathrm{~mm}$ when the added amount of $\mathrm{B}_{2} \mathrm{O}_{3}$ was $<20 \%$. To improve the lead removal efficiency of acid leaching, the large reduction product was broken into powders with particle size of $<74 \mu \mathrm{m}$.

Fig. 8(a) shows the lead removal rates of the acid leaching process obtained at different temperatures when the added amount of $\mathrm{B}_{2} \mathrm{O}_{3}$ and holding time were fixed at $20 \%$ and 30 mins, respectively. Lead removal rate was only approximately $34.88 \%$ at $700{ }^{\circ} \mathrm{C}$, which rapidly increased to $99.80 \%$ at $1000^{\circ} \mathrm{C}$. The growth of lead removal rate was then slowed down and reached its maximum of $99.98 \%$ at $1300^{\circ} \mathrm{C}$. In addition, a part of $\mathrm{PbO}$ had already been removed from the glass phase before the acid leaching process. Therefore, lead removal rates could be divided into two parts. The first part of $\mathrm{PbO}$ could be removed by the thermal process, and the other parts of $\mathrm{PbO}$ could be removed by an acid leaching process. As shown in Fig. 5, at $1000^{\circ} \mathrm{C}$, the lead removal rate caused by the thermal process was only $17.60 \%$, and about $82.20 \%$ of $\mathrm{PbO}$ was removed by the acid leaching process. When the temperature was raised to $1300^{\circ} \mathrm{C}$, the lead removal rate caused by the thermal process was predominant at $85.45 \%$. Therefore, carbon thermal reduction shows a great strengthening effect on the phase separation process at high temperature. The effect of the temperature on the lead removal rate can be illustrated as follows: $\mathrm{PbO}$ was distributed evenly in the funnel glass before the thermal treatment. Unlike $\mathrm{PbO}, \mathrm{Pb}$ cannot be distributed in the glass phase. At the beginning of the thermal reduction treatment, $\mathrm{PbO}$ near the surface of the residue was reduced to $\mathrm{Pb}$ and located on the surface of the residue. Thus, the PbO content of the residue surface was lower than that in the inner portion and $\mathrm{PbO}$ concentration gradient was formed. The concentration gradient of $\mathrm{PbO}$ caused the flow of $\mathrm{PbO}$ from the inner glass phase of the surface. The migration velocity of $\mathrm{PbO}$ was

\section{(a)}
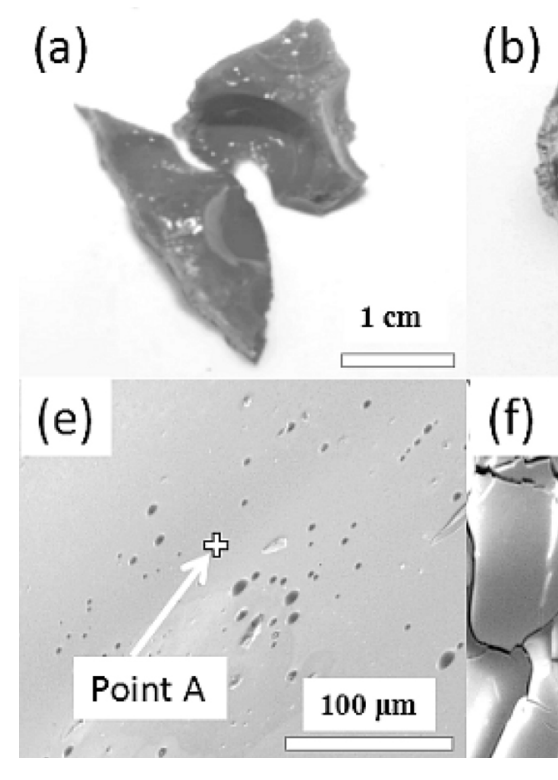

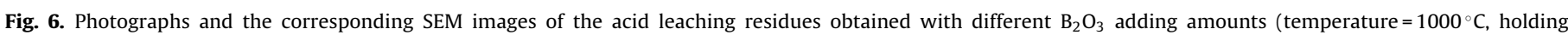
time $=30 \mathrm{~min}$ ). (a) $0 \%$; (b) 10\%; (c) 20\%; (d) 30\%; (e) (h) was the corresponding SEM images of (a) (d).

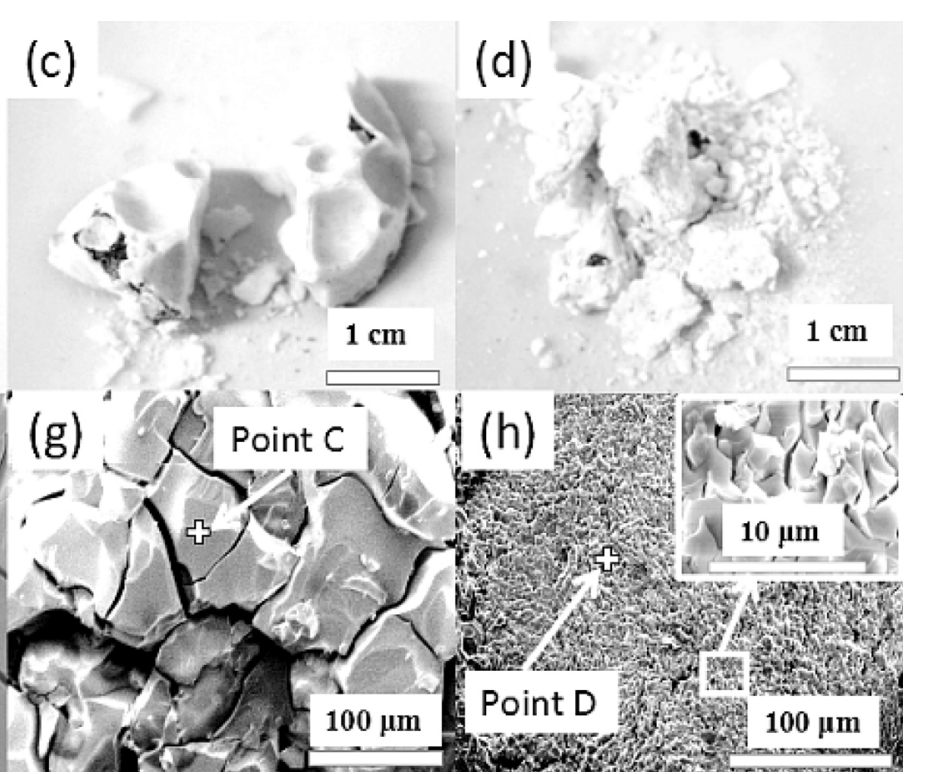




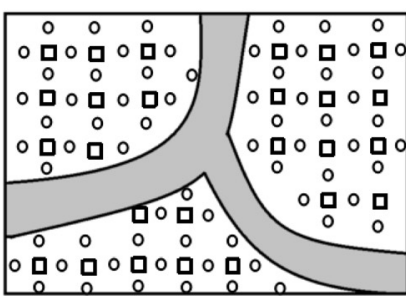

Before thermal treatment

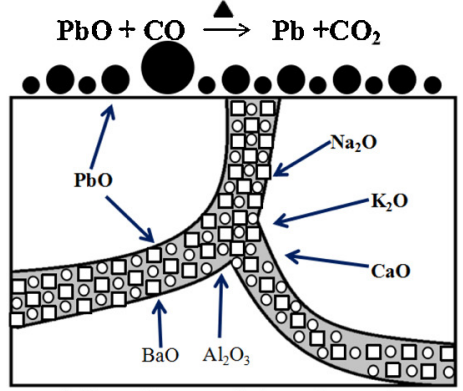

After thermal treatment

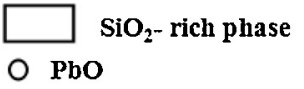

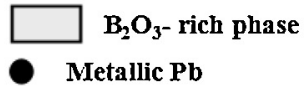

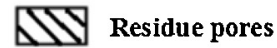

$\square \mathrm{Na}_{2} \mathrm{O}, \mathrm{K}_{2} \mathrm{O}, \mathrm{CaO}, \mathrm{BaO}, \mathrm{Al}_{2} \mathrm{O}_{3}$

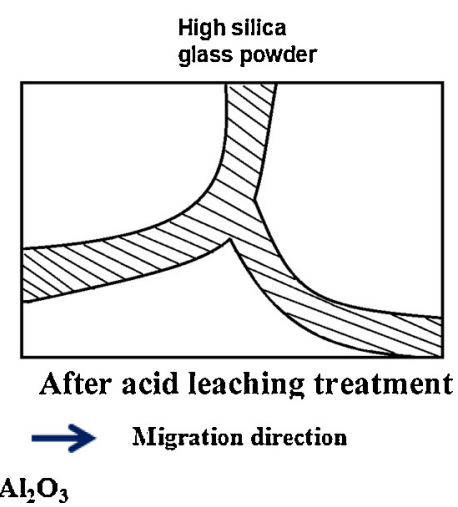

High silica

Fig. 7. Schematic diagram of the migration and transformation rule for PbO during the carbon thermal enhanced glass phase separation process. mainly influenced by the viscosity of the glass phase, which quickly decreased with the increase in temperature. The higher the temperature, the faster the migration velocity of PbO. Accordingly, the reduction rate of $\mathrm{PbO}$ increased rapidly with the increase in temperature. Meanwhile, $\mathrm{PbO}$ could quickly migrate from the silicon oxide phase to the boric oxide phase when the viscosity of the glass phase was lower at high temperature. Once PbO was concentrated in the boron-rich phase, it could be efficiently removed by an acid leaching treatment. Therefore, temperature plays an important role in the lead removal rate.

Fig. 8(b) shows lead removal rates with different added amounts of $\mathrm{B}_{2} \mathrm{O}_{3}$ when the temperatures and holding time were respectively fixed at $1000^{\circ} \mathrm{C}$ and 30 mins. Lead removal rates were only about $30.03 \%$ when no $\mathrm{B}_{2} \mathrm{O}_{3}$ was mixed with a funnel glass. Thereafter, lead removal rates rapidly increased from $61.80 \%$ to $99.27 \%$ when the added amount was increased from $5 \%$ to $15 \%$. The growth of the lead evaporation rate then slowed down, while the lead removal rates increased from $99.80 \%$ to $99.96 \%$ when the added amount was increased from $20 \%$ to $30 \%$. The effect of the $\mathrm{B}_{2} \mathrm{O}_{3}$ added amount on the lead removal rate could be illustrated as follows: (1) After thermal reduction treatment, the unreduced $\mathrm{PbO}$ and many other metal oxides were mainly concentrated in the borate phase. The structure of the borate-rich phase was largely dependent on the added amount of $\mathrm{B}_{2} \mathrm{O}_{3}$. When this amount was $<15 \%$, the boraterich phase was isolated, thereby greatly limiting the dissolution rate of the boric oxide phase. When the $\mathrm{B}_{2} \mathrm{O}_{3}$ added amount was $>15 \%$, the interconnected structure of the boric oxide phase was formed so that most of the unreduced $\mathrm{PbO}$ that concentrated in the borate phase was completely leached out with the dissolution of the borate phase. (2) $\mathrm{B}_{2} \mathrm{O}_{3}$ could also reduce the viscosity of the glass phase, especially in a high-temperature environment. The lower viscosity can speed up the migration velocity of $\mathrm{PbO}$ from the inner part to the surface of the residue. As shown in Fig. 5, approximately $85.45 \%$ of $\mathrm{PbO}$ was reduced to metallic $\mathrm{Pb}$ and separated from the glass phase during the thermal treatment when the $\mathrm{B}_{2} \mathrm{O}_{3}$ added amount, temperature, and reaction time were fixed at $20 \%, 1300{ }^{\circ} \mathrm{C}$, and 30 mins. The content of PbO left in the residue was no more than $15 \%$, which can be easily removed by the following acid leaching treatment. Thus, carbon thermal reduction was a useful method to enhance the glass phase separation.

Fig. 8(c) shows the effect of the holding time on lead removal rates when the temperatures and $\mathrm{B}_{2} \mathrm{O}_{3}$ added amount were respectively fixed at $1000^{\circ} \mathrm{C}$ and $30 \mathrm{~min}$. The lead removal rate was already at $99.80 \%$ when the holding time was only $30 \mathrm{~min}$ and reached its maximum of $99.98 \%$ at $240 \mathrm{~min}$. We can conclude that $\mathrm{PbO}$ could be quickly concentrated in the borate-rich phase under high temperature and efficiently leached out by hot acid. Therefore,
Table 5

Chemical composition of the acid leaching residue by ICP-OES.

\begin{tabular}{ll}
\hline Elements & wt\% \\
\hline $\mathrm{SiO}_{2}$ & 95.19 \\
$\mathrm{Na}_{2} \mathrm{O}$ & 2.97 \\
$\mathrm{~B}_{2} \mathrm{O}_{3}$ & 0.98 \\
$\mathrm{Al}_{2} \mathrm{O}_{3}$ & 0.49 \\
$\mathrm{BaO}$ & 0.12 \\
$\mathrm{PbO}$ & 0.08 \\
$\mathrm{Fe}_{2} \mathrm{O}_{3}$ & 0.06 \\
$\mathrm{NiO}$ & 0.02 \\
$\mathrm{CaO}$ & 0.01 \\
$\mathrm{~K}$ & 0.01 \\
\hline
\end{tabular}

the effect of holding time on the lead removal rate was not obvious. However, the metallic $\mathrm{Pb}$ and $\mathrm{B}_{2} \mathrm{O}_{3}$ were volatile under the condition of high temperature. If the processing time was extremely long, more metallic lead might evaporate into the gas phase and cause harm to human health. Based on the consideration of lead removal rate and energy consumption, $30 \mathrm{~min}$ was recommended as the optimum holding time with temperature and $\mathrm{B}_{2} \mathrm{O}_{3}$ added amount fixed at $1200^{\circ} \mathrm{C}$ and $20 \%$, respectively.

\subsection{Properties of acid leaching residue}

The reduction residue was black, but it turns white after exposure to hot acid of $\mathrm{HNO}_{3}$ for $60 \mathrm{~min}$, as shown in Fig. 9(a). Fig. 9(b) shows that the acid leaching residue mainly had an irregular shape and the particle size ranged from 1.11 to $48.12 \mu \mathrm{m}$ with an average of $9.43 \mu \mathrm{m}$. To further understand the chemical composition of the acid leaching residue, the residue $\left(1000{ }^{\circ} \mathrm{C}, 20 \% \mathrm{~B}_{2} \mathrm{O}_{3}\right.$, and $30 \mathrm{~min}$ ) was analyzed by ICP-OES; the results are shown in Table 5. Under optimum experimental conditions, $20 \%$ of $\mathrm{B}_{2} \mathrm{O}_{3}$ was added into the funnel glass. After the acid leaching treatment, most of the $\mathrm{B}_{2} \mathrm{O}_{3}$ was leached out and the $\mathrm{B}_{2} \mathrm{O}_{3}$ content of the leaching residue was $0.87 \%$. Only $0.08 \%$ of $\mathrm{PbO}$ was left in the residue, which was much lower than that of the raw funnel glass. The main composition of the acid leaching residue was $\mathrm{SiO}_{2}$, which accounted for $95.19 \%$, while the other elements were $\mathrm{Na}_{2} \mathrm{O}$ (2.97\%), $\mathrm{B}_{2} \mathrm{O}_{3}$ $(0.98 \%), \mathrm{Al}_{2} \mathrm{O}_{3}(0.79 \%), \mathrm{BaO}(0.12 \%)$, and $\mathrm{F}_{2} \mathrm{O}_{3}(0.06 \%)$. The chemical composition of the acid leaching residue indicated that $\mathrm{PbO}$, $\mathrm{Na}_{2} \mathrm{O}, \mathrm{K}_{2} \mathrm{O}, \mathrm{Al}_{2} \mathrm{O}_{3}$, and $\mathrm{CaO}$ were mainly concentrated in the boric oxide phase during the thermal reduction process. However, about $30 \%$ of $\mathrm{Na}_{2} \mathrm{O}$ residue was left in the silica-rich phase probably because of insufficient annealing treatment. In this experiment, the process chamber was slowly cooled down to room temperature so that the annealing time between $500^{\circ} \mathrm{C}$ and $580^{\circ} \mathrm{C}$ was 

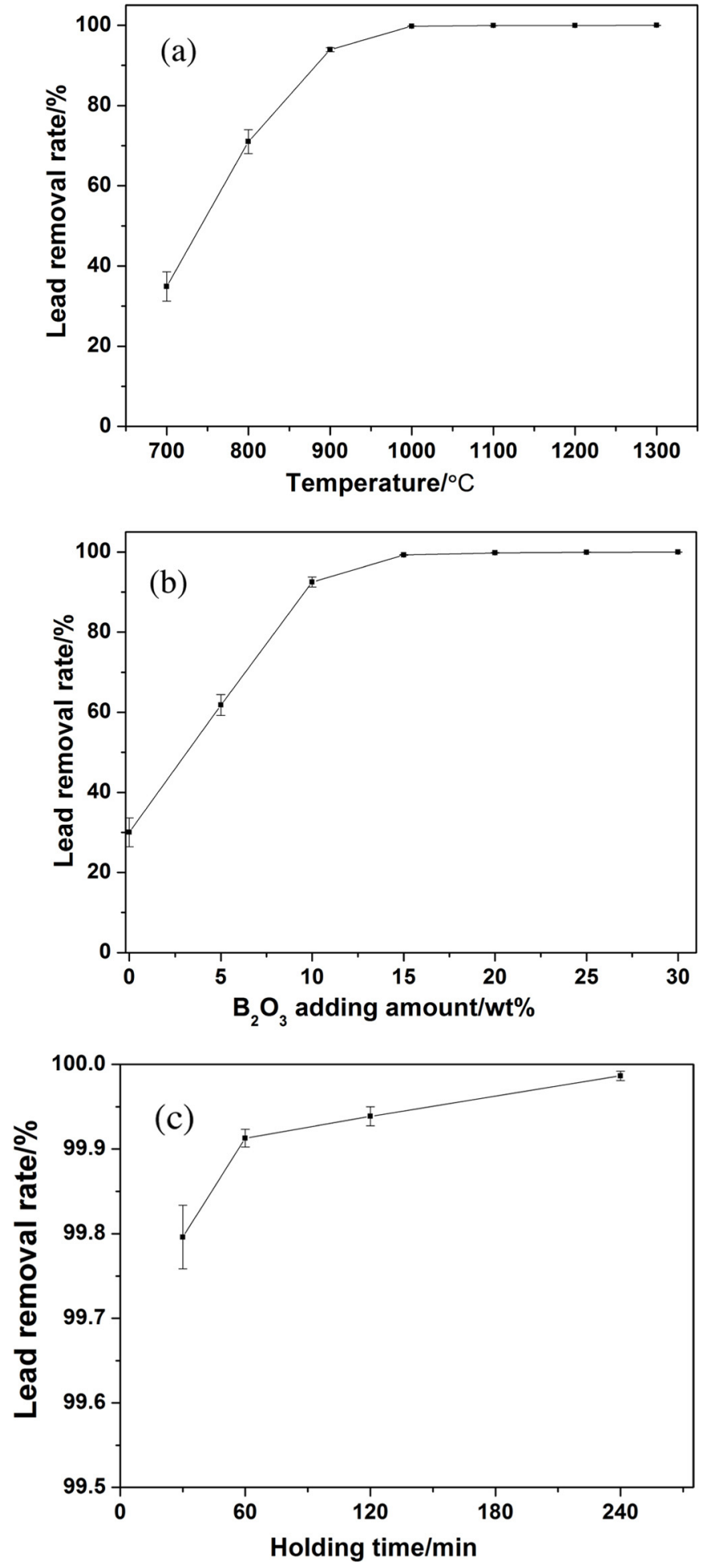

Fig. 8. Effects of various parameters on lead removal rate of acid leaching treatment (a). Effect of temperature on lead removal rate $\left(\mathrm{B}_{2} \mathrm{O}_{3}\right.$ adding amount $=20 \%$ and holding time $=30 \mathrm{~min}$ ). (b). Effect of $\mathrm{B}_{2} \mathrm{O}_{3}$ adding amount on lead removal rate (temperature $=1000^{\circ} \mathrm{C}$ and holding time $=30 \mathrm{~min}$ ). (c). Effect of holding time on lead removal rate (temperature $=1000^{\circ} \mathrm{C}$ and $\mathrm{B}_{2} \mathrm{O}_{3}$ adding amount $=20 \%$ ).

no more than $30 \mathrm{~min}$, which could be ignored when compared with the traditional phase separation process. Therefore, sufficient annealing treatment may increase the enrichment degree of $\mathrm{Na}_{2} \mathrm{O}$ in the boric oxide phase to further increase the purity of the silica. (a)

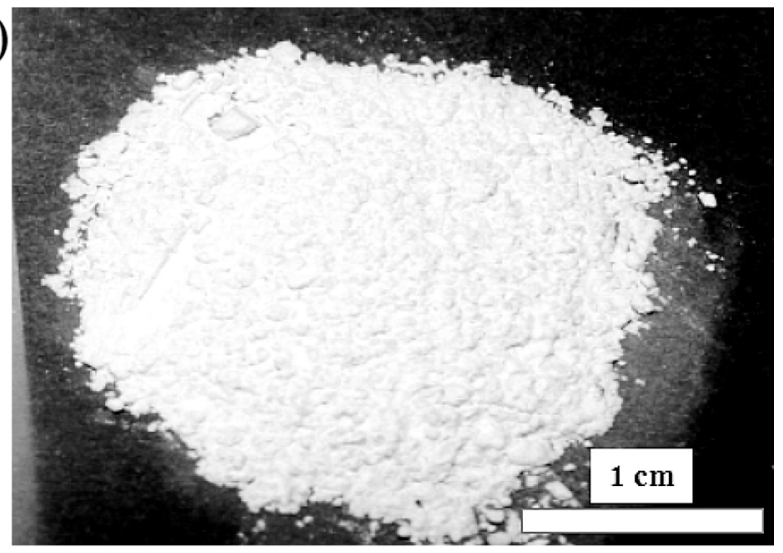

(b)

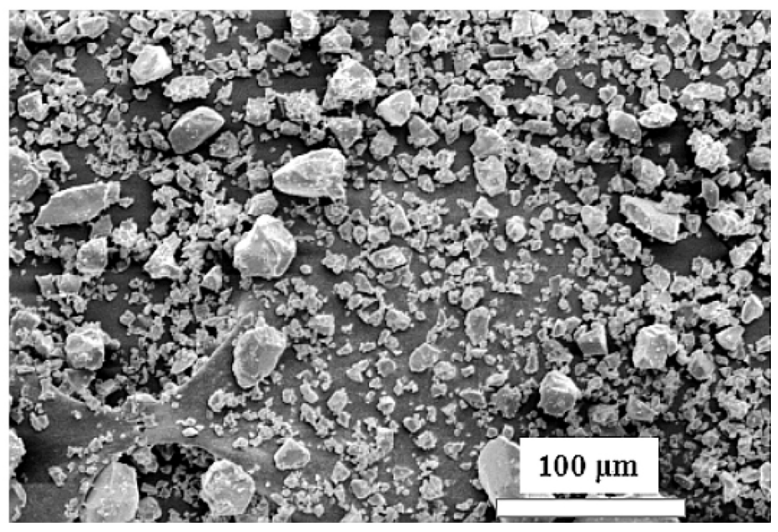

Fig. 9. Photograph (a) and the corresponding SEM image (b) of the acid leaching residue with the temperature, $\mathrm{B}_{2} \mathrm{O}_{3}$ adding amount and reaction time were fixed at $1000{ }^{\circ} \mathrm{C}, 20 \%$ and $30 \mathrm{~min}$, respectively.

\section{Conclusions}

In this study, high silica glass powder was prepared from the CRT funnel glass, together with the lead recovery by the carbon-thermal reduction that enhanced the glass phase-separation process. $\mathrm{B}_{2} \mathrm{O}_{3}$ could be used as a pore-forming, fluxing, and phase separation agent to improve the lead removal rate. During the thermal reduction process, three different phases were obtained, namely, metallic $\mathrm{Pb}$, boric oxide, and silicon oxide. A part of the $\mathrm{PbO}$ contained in the funnel glass was reduced to metallic $\mathrm{Pb}$ by $\mathrm{CO}$ and detached from the glass phase. The unreduced $\mathrm{PbO}$ that accompanied many other metal oxides (including $\mathrm{Na}_{2} \mathrm{O}, \mathrm{K}_{2} \mathrm{O}, \mathrm{Al}_{2} \mathrm{O}_{3}, \mathrm{BaO}$, and $\mathrm{CaO}$ ) were mainly concentrated in the boric oxide phase. After the acid leaching process, the metallic $\mathrm{Pb}$ phase on the surface of the residue and $\mathrm{PbO}$ contained in the boric oxide phase were completely leached out. Experimental results showed that the lead recovery rate increased with an increase in temperature, $\mathrm{B}_{2} \mathrm{O}_{3}$ added amount, and holding time. The optimum temperature, carbon powder added amount, and holding time for the process were $1000^{\circ} \mathrm{C}, 20 \%$, and $30 \mathrm{~min}$, respectively, and the lead removal rate was $99.80 \%$. The $\mathrm{SiO}_{2}$ content of the acid leaching residue was 95.19\%. Therefore, the findings of this study may be an applicable option for the CRT funnel glass detoxification and reutilization.

\section{Acknowledgements}

This work was made possible by the financial supports from the National Natural Science Founds of China (51508165), Henan Key Laboratory Cultivation Base of Environmental Protection and Ecological Remediation in Mining Area (KF2014-02) and the Science 
and Technology Research Key Project for Basic Research of Henan Province Education Department (13140055).

\section{References}

[1] M.J. Chen, F.S. Zhang, J.X. Zhu, Effective utilization of waste cathode ray tube glass-crystalline silicotitanate synthesis, J. Hazard. Mater. 182 (2010) 45-49.

[2] I.C. Nnorom, O. Osibanjo, M.O.C. Ogwuegbu, Global disposal strategies for waste cathode ray tubes, Resour. Conserv. Recyl. 55 (2011) 275-290.

[3] F. Méar, P. Yot, M. Cambon, M. Ribes, The characterization of waste cathode-ray tube glass, Waste Manage. 26 (2006) 1468-1476.

[4] P.G. Yot, F.O. Mear, Characterization of lead, barium and strontium leachability from foam glasses elaborated using waste cathode ray-tube glasses, J. Hazard. Mater. 185 (2011) 236-241.

[5] M. Yamashita, A. Wannagon, S. Matsumoto, T. Akai, H. Sugita, Y. Imoto, T. Komai, H. Sakanakura, Leaching behavior of CRT funnel glass, J. Hazard. Mater. 184 (2010) 58-64.

[6] H. Zhao, C.S. Poon, T.C. Ling, Utilizing recycled cathode ray tube funnel glass sand as river sand replacement in the high-density concrete, J. Clean. Prod. 51 (2013) 184-190.

[7] F. Méar, P. Yot, M. Ribes, Effects of temperature, reaction time and reducing agent content on the synthesis of macroporous foam glasses from waste funnel glasses, Mater. Lett. 60 (2006) 929-934.

[8] T.-C. Ling, C.-S. Poon, W.-S. Lam, T.-P. Chan, K.K.-L. Fung, Utilization of recycled cathode ray tubes glass in cement mortar for X-ray radiation-shielding applications, J. Hazard. Mater. 199-200 (2012) 321-327.

[9] M. Chen, F.-S. Zhang, J. Zhu, Lead recovery and the feasibility of foam glass production from funnel glass of dismantled cathode ray tube through pyrovacuum process, J. Hazard. Mater. 161 (2009) 1109-1113.

[10] M. Xing, F.-S. Zhang, Nano-lead particle synthesis from waste cathode ray-tube funnel glass, J. Hazard. Mater. 194 (2011) 407-413.

[11] G. Grause, K. Takahashi, T. Kameda, T. Yoshioka, Lead removal from cathode ray tube glass by the action of calcium hydroxide and poly(vinyl chloride), Thermochim. Acta 596 (2014) 49-55.
[12] T. Okada, S. Yonezawa, Energy-efficient modification of reduction-melting for lead recovery from cathode ray tube funnel glass, Waste Manage. 33 (2013) $1758-1763$.

[13] T. Okada, S. Yonezawa, Reduction-melting combined with a $\mathrm{Na}_{2} \mathrm{CO}_{3}$ flux recycling process for lead recovery from cathode ray tube funnel glass, Waste Manage. 34 (2014) 1470-1479.

[14] T. Okada, F. Nishimura, S. Yonezawa, Removal of lead from cathode ray tube funnel glass by combined thermal treatment and leaching processes, Waste Manage. 45 (2015) 343-350.

[15] S. Ryo, K. Hisashi, K. Masahiro, I. Hideaki, Development of an eco-friendly material recycling process for spent lead glass using a mechanochemical process and $\mathrm{Na}_{2}$ EDTA reagent, Environ. Sci. Technol. 42 (2008) 4159-4164.

[16] A.J. Saterlay, S.J. Wilkins, R.G. Compton, Towards greener disposal of waste cathode ray tubes via ultrasonically enhanced lead leaching, Green Chem. 3 (2001) 149-155

[17] F.O. Méar, P.G. Yot, A.V. Kolobov, M. Ribes, M.-F. Guimon, D. Gonbeau, Local structure around lead, barium and strontium in waste cathode-ray tube glasses, J. Non-Cryst. Solids 353 (2007) 4640-4646.

[18] M. Xing, Y. Wang, J. Li, H. Xu, Lead recovery and glass microspheres synthesis from waste CRT funnel glasses through carbon thermal reduction enhanced acid leaching process, J. Hazard. Mater. 305 (2015) 51-58.

[19] M.E. Nordberg, Properties of some Vycor-brand glasses, J. Am. Ceram. Soc. 27 (2006) 299-305.

[20] D. Enke, F. Janowski, W. Schwieger, Porous glasses in the 21st century-a short review, Microporous Mesoporous Mater. 60 (2003) 19-30.

[21] D.H. Kim, W.T. Kim, E.S. Park, N. Mattern, J. Eckert, Phase separation in metallic glasses, Prog. Mater. Sci. 58 (2013) 1103-1172.

[22] D. Chen, H. Masui, H. Miyoshi, T. Akai, T. Yazawa, Extraction of heavy metal ions from waste colored glass through phase separation, Waste Manage. 26 (2006) 1017-1023.

[23] C.H. Lee, C.S. Hsi, Recycling of scrap cathode ray tubes, Environ. Sci. Technol. 36 (2002) 69-75 